\title{
Experiment Work on the Effect of Hygrothermal Environment on the Mechanical Behaviour of Natural Fiber Reinforced Epoxy Composites
}

\author{
C.M. Meenakshi, Jeeva Bharathi, S Karthikeyan
}

\begin{abstract}
In todays industrial scenario the need for bio degradable matreials in all the fields including automobile and mechanical field is increasing. To satisfy this needs we need to find an alternative natural sorce based materials with similar properties. These natural products attribute can be enhanced using some processing techniques and by adding suitable chemicals. Composite materials are the one which is ruling our world and the need for them is high due ton their high srength to weight ratio. Thus composite research is happening in large number throughout the world, in which the hybrid composite manufacturing has been wide range of investigations. The composites have superior properties like light weight, low density, stiffness, and better mechanical properties. The present work aims on mechanical and thermal behaviours of GKG, GAG, and KGA fibre reinforced epoxy composites. Hand layup method used for fabricate hybrid composite laminates. Work has been carried out to explore the tensile strength, Hygrothermal exposure. For testing and analysis, the specimens are cut as per ASTM standards.
\end{abstract}

Keyword : Composite materials, Hypothermal Exposure

\section{INTRODUCTION}

Regular fiber fortified composites are as a rule progressively utilized in many building applications like sliding boards, orientation, linkages, bushings. Polymer composite materials regularly have mechanical and physical properties that improve them appropriate for a wide scope of uses than the individual composite parts[1],[3],[5]. The utilization of normal fiber advancement of polymeric materials that are created from manageable and naturally composites ordinarily have a fiber or molecule stage that is stiffer and more grounded than the constant framework stage and serve "composites are multifunctional material frameworks that give qualities not realistic from any discrete material. The NFC removed flax FIBERs have been found to have quality $20 \%$ higher than those extricated precisely. The Fabrication Reinforced Composites (FRC) is expanding quickly in the car, aviation and wind vitality parts due to their high explicit

Revised Manuscript Received on August 22, 2019.

CM Meenakshi, Department of Mechanical Engineering, Bharath Institute of Higher Education and Research, Chennai, Tamilnadu, India. Email: cmmeenakshidhanush@gmail.com

Jeeva Bharathi, Department of Mechanical Engineering, Bharath Institute of Higher Education and Research, Chennai, Tamilnadu, India. Email: jeevabharathi013@gmail.com

S. Karthikeyan, Department of Mechanical Engineering, Bharath Institute of Higher Education and Research, Chennai, Tamilnadu, India. Email: karthi.keyan5@yahoo.co.in quality and modulus. This project work aimed at the usages of Natural plant fibres such as flax, sisal and producing a natural

based material composite laminate made from renewable agricultural and forestry feedstock. The natural fibre used will be chemically treated to improves its performance and the laminate will be prepared with this treated fibres. Then it will be subjected to mechanical characterization and analysed[2],[4],[6].

\section{RELATED WORKS}

In 2002, V.P. Della, I. Kuhn, D. Hotza contemplated on Rice husk fiery remains as a substitute hotspot for dynamic silica generation. The investigation was about portrayal of dynamic silica with high explicit surface territory from rice husk fiery debris. They finished up result as rice husk fiery remains in the wake of wearing out at $700{ }^{\circ} \mathrm{C}$ for 6 hours will give high measure of silica.

In 2012, A. Gowthami K. Ramanaiah A.V. Ratna Prasad, K. Hema Chandra Reddy, K. Mohana Rao, G. Sridhar Babu considered on Effect of Silica on Thermal and Mechanical Properties of Sisal Fiber Rein-constrained Polyester Composites they directed ductile test, sway test, explicit warmth limit test. They finished up result as expansion of silica with the composite shows great in elasticity, tractable modulus, sway quality and explicit warmth limit than composite without silica content.

In 2014, Elammaran Jayamania, SininHamdanb, MdRezaurRahmanb, MdKhusairy Bin Bakri made near investigation of dielectric properties of half breed normal fiber composites. The investigation was about the jute fiber, and bamboo fiber fortified with polypropylene and polyester on hot press strategy. They directed elastic test, flexural test, and effect test. Jute, bamboo strengthened unsaturated polyester cross breed composites have higher dielectric properties than jute, bamboo fortified polypropylene composites. Henceforth the previous composite is favored than the last mentioned[7],[9],[11]. 


\section{SAMPLES FOR MECHANICAL CHARACTERIZATION}

Composite overlays arranged are cut into littler examples of ASTM gauges, for different test methodology and the measured examples are appeared in the approaching figures.

\section{A. Tensile Strength}

The ductile test is performed in the widespread testing machine. Numerous composite materials are solid in hub pressure, and pliable test examples must, by their temperament, be grasped in some way for testing. The elastic test is for the most part performed on level examples. The regularly utilized examples for tractable test are the pooch bone sort, i.e., the example has a steady width focal (gage) district, yet is broadened at the finishes to decrease the worries there, by expanding the cross sectional territory (ASTM D 638, 1996). Thus, if neighborhood harm is instigated it ideally won't be sufficient to cause disappointment in these low pressure areas[8],[10],[12].

During the test a uni-hub burden is applied through both the parts of the bargains. The setup of elastic test example appeared in figure 1

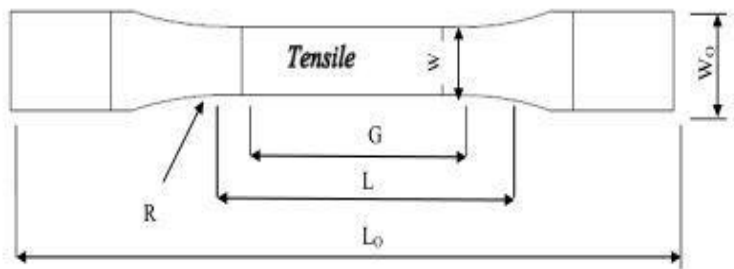

Figure 1- Tensile test Specimen

\section{B. Hygrothermal Test}

Tests are cut into the size of $(165 \mathrm{~mm} \times 19 \mathrm{~mm} \times 3 \mathrm{~mm})$ in concurring with ASTM benchmarks D-638. The examples were tried by utilizing hygrothermal testing gear, it comprise of the compartment loaded up with demineralized water of $\mathrm{pH}$ worth is 7 and TDS worth is under 300. Thinking about the climate conditions in India, the test temperature for hygrothermal test was fixed as $60{ }^{\circ} \mathrm{C}$. The examples were weighed independently by utilizing an electronic parity to maintain a strategic distance from abrupt effect on examples we place examples at $44{ }^{\circ} \mathrm{C}$ and when the temperature arrived at $60{ }^{\circ} \mathrm{C}$ the example were screened to the hygrothermal molding for $72 \mathrm{~h}$. After the hygrothermal introduction, the examples were expelled from the compartment and the abundance dampness superficially were evacuated after that weighed again and the measure of dampness consumed are determined. The examples were encased in aluminum foil to stay away from dampness misfortune (or) dampness gain[13],[15],[17].

\section{RESULT AND DISCUSSION}

\section{A. Tensile Strength}

\begin{tabular}{|c|c|c|c|c|c|c|}
\hline \multirow{2}{*}{$\begin{array}{c}\text { Composite } \\
\text { Type }\end{array}$} & \multicolumn{6}{|c|}{$\begin{array}{c}\text { TENSILE STRENGTH } \\
\text { (NMM2) }\end{array}$} \\
\cline { 2 - 7 } & 1 & 2 & 3 & 4 & 5 & Average \\
\hline GKG & 81.78 & 118.52 & 102.54 & 62.44 & 91.77 & 91.41 \\
\hline GAG & 54.89 & 53.81 & 83.12 & 71.14 & 74.48 & 67.48 \\
\hline KGA & 14.97 & 48.38 & 41.52 & 49.59 & 36.79 & 38.25 \\
\hline
\end{tabular}

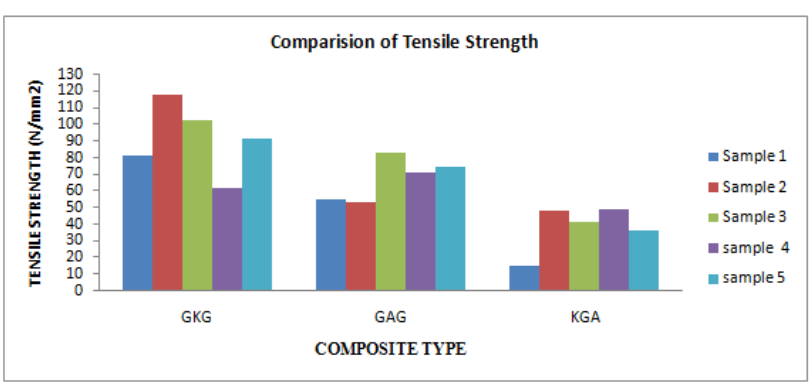

\section{B. Hygrothermal Analysis:}

The after Hygrothermal treated tensile test result shows that the hybrid composite is showing equally good performance to glass fiber reinforced composite and natural fiber reinforced composite is also showing positive result. The maximum strength obtained by GKG and GAG when compare to KGA.

\begin{tabular}{|c|c|c|c|c|}
\hline \multirow{2}{*}{ Composite type } & \multicolumn{4}{|c|}{ Tensile Strength N/mm ${ }^{2}$} \\
\cline { 2 - 5 } & Sample 1 & Sample 2 & Sample 3 & Average \\
\hline GKG & 68.97 & 70.37 & 63.62 & 67.65 \\
\hline GAG & 69.86 & 63.95 & 58.92 & 64.24 \\
\hline KGA & 29.88 & 32.08 & 28.89 & 30.28 \\
\hline
\end{tabular}

\section{Comparison of Tensile Strength Before and After Hygrothermal Treatment}

The Tensile test was carried out before and after Hygrothermal treatment. By comparing both values, we found that the tensile strength decreases lightly after hygrothermal treatment as compare to before hygrothermal treatment in GKG, GAG and KGA[14],[16],[18]. The before and after Hygrothermal treatment tensile strength decrement range very less in GAG, when compare to others. It is inferred that GKG and GAG can be act as promising replacement in structural application demanding nominal tensile strength than KGA[19],[21],[22]. The results are shown in table.

\begin{tabular}{|c|c|c|}
\hline Composite Type & $\begin{array}{c}\text { Before Hygrothermal Treatment } \\
\text { Tensile Strength(N/MM2) }\end{array}$ & $\begin{array}{c}\text { After Hygrothermal Treatment } \\
\text { Tensile Strength(NMM2) }\end{array}$ \\
\hline GKG & 91.41 & 67.65 \\
\hline GAG & 67.48 & 64.24 \\
\hline KGA & 38.25 & 30.28 \\
\hline
\end{tabular}




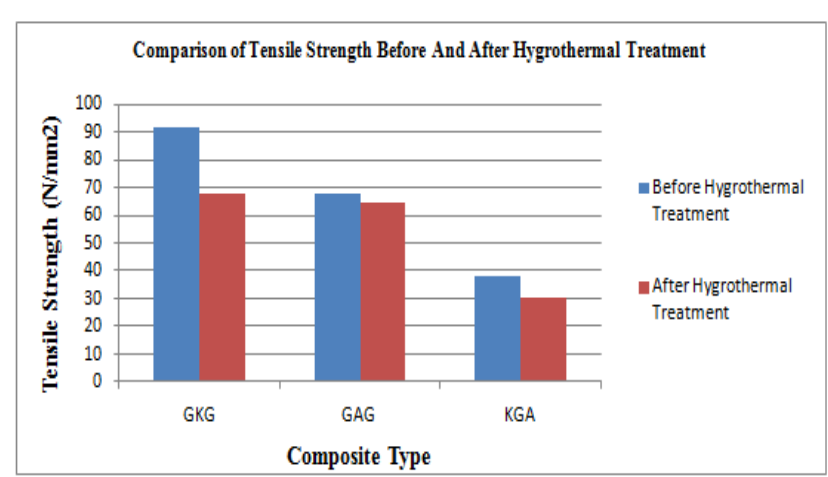

\section{CONCLUSION}

Three types of composite laminates are fabricated using hand layup method with Glass, Kenaf and Aloe vera fibers in Epoxy Resins and their mechanical and thermal properties are studied. From the results the following conclusions are made. - From the tensile strength test it is understood that GKG (Glass/Alovera laminate) is having higher tensile strength compare to GAG and KGA.

- From hygrothermal results, and by comparing the before and after hygrothermal treatment tensile strength , GAG and KGA hybrid laminates shows less strength Reduction.

The overall results shows, the hybridization of natural fiber along with the glass fiber has good impact on the thermal capacity of the composites. Also we found that, if the proportion of natural fibre increased then the thermal ability will be increased.

\section{REFERENCES}

1. Tatikonda, N.C. \& Naveenchandran, P. 2019, "The behaviour of a compression ignition engine under the influence of diesel and microalgae biodiesel blends", International Journal of Mechanical and Production Engineering Research and Development, vol. 9, no. 4, pp. 447-456.

2. Tatikonda, N.C. \& Naveenchandran, P. 2019, "An experimental assessment on the impact of injection pressure on the characteristics of a diesel engine powered with the blend of diesel and microalgae biodiesel", International Journal of Engineering and Advanced Technology, vol. 8, no. 6, pp. 3284-3291.

3. Karthikeyan, S., Raman Balasubramanian, S.R., Ramesh, B., Raghul, S. \& Sathish Kumar, S. 2019, "The automatic solar tracker chronicles", International Journal of Recent Technology and Engineering, vol. 8, no. 1, pp. 312-315.

4. Hema, R., Sundararajan, M. \& Balaji, S. 2019, "Smartphone control robot with automatic firing gun", International Journal of Innovative Technology and Exploring Engineering, vol. 8, no. 9 Special Issue 3, pp. 625-627.

5. Saritha, B., Chockalingam, M.P. \& Aswathy, M. 2019, "Degradation of anionic dye using $\mathrm{Fe} / \mathrm{Tio} 2$ composite by photocatalysis", International Journal of Innovative Technology and Exploring Engineering, vol. 8, no. 9 Special Issue 3, pp. 788-791.

6. Saritha, B., Maria Subashini, L. \& Aswathy, M. 2019, "Utilization of spent coffee grounds for compost production", International Journal of Innovative Technology and Exploring Engineering, vol. 8, no. 9 Special Issue 3, pp. 908-910.

7. Fernando, J.K., Meikandaan, T.P. \& Hemapriya, M. 2019, "Better utilisation of bottom ash in coal fired thermal power station", International Journal of Innovative Technology and Exploring Engineering, vol. 8, no. 9 Special Issue 3, pp. 898-900.

8. Kumar, K.S., Kiruthiga, K. \& Thendral, S. 2019, "Experimental analysis on fractional substitution of bond by utilizing rice husk cinder", International Journal of Innovative Technology and Exploring Engineering, vol. 8, no. 9 Special Issue 3, pp. 1163-1165.

9. Vignesh, P., Madan, P., Mohankumar, D. \& Naveenchandran, P. 2019, "Optimization of four stroke c.i. engine performance by using statistical techniques (mathematical method)", International Journal of Recent Technology and Engineering, vol. 8, no. 2, pp. 1685-1691

10. Bharanidharan, S., Sathiyamurthy, K. \& Sheeba, B. 2019, "Using co-precipitation method determining synthesis and characterization of fe doped zinc oxide nanoparticles", International Journal of Innovative Technology and Exploring Engineering, vol. 8, no. 9 Special Issue 3, pp. 705-707.

11. Jeevanandan, D. \& Vino, J.A. 2019, "Heat recovery from boiler blowdown water by using heat exchanger in thermal power plant", International Journal of Mechanical and Production Engineering Research and Development, vol. 9, no. 3, pp. 219-222.

12. Rakesh, N.L., Balambica, V. \& Kannan, S. 2019, "Biogas extraction from waste orange peel by digestion process", International Journal of Mechanical and Production Engineering Research and Development, vol. 9, no. 3, pp. 323-330.

13. Meenakshi, C.M. \& Krishnamoorthy, A. 2019, "The mechanical characterization of mono and hybrid fiber reinforced composites using experimental and finite element analysis methods", International Journal of Mechanical and Production Engineering Research and Development, vol. 9, no. 3, pp. 189-196.

14. Mohankumar, D., Prem Jayakumar, M., Sabarsish, R. \& Naveen Chandran, P. 2019, "Modeling and experimental investigation on centrifugal blower by computational fluid dynamics", International Journal of Mechanical and Production Engineering Research and Development, vol. 9, no. 3, pp. 331-340.

15. Balambica, V., Deepak, V. \& Kumar, S. 2019, "Design and efficiency of an asymmetric gear", International Journal of Mechanical and Production Engineering Research and Development, vol. 9, no. 3, pp. 223-230.

16. Manavalan, S., Balakrishnan, G. \& Ramasubramaniam, S. 2019, "An effect of cobalt oxide nano additive with biodiesel blends using cidi diesel engine", International Journal of Mechanical and Production Engineering Research and Development, vol. 9, no. 3, pp. 211-218.

17. Golden Renjith Nimal, R.J., Sivakumar, M. \& Esakkimuthu, G. 2019, "An investigation on mechanical properties and microstructure of $\mathrm{mg} / \mathrm{al}$ alloys using $\mathrm{zn}$ interlayer during diffusion bonding", International Journal of Mechanical and Production Engineering Research and Development, vol. 9, no. 3, pp. 125-130.

18. Hariharan, R., Raja, R. \& Vasu, S. 2019, "Mechanical and tribological behaviour of thin tan coating produced on AISI 1018 substrate by DC magnetron sputtering", International Journal of Recent Technology and Engineering, vol. 7, no. 6, pp. 591-598

19. Manavalan, S., Rai, R., Kumar, R.R., Chaudhary, R.K. \& Chaudhary, S.K. 2019, "Impact of modified piston - A review", International Journal of Recent Technology and Engineering, vol. 8, no. 6, pp 616-620.

20. Manavalan, S., Gopi, A., Arivarasu, J., Abishek Ahi, A. \& Chandru, S. 2019, "Review on ceramic disc brake system", International Journal of Recent Technology and Engineering, vol. 7, no. 6, pp. 612-615.

21. Sabarish, R. \& Jeya Kumar, M.P. 2019, "The design and analysis of piston - Steady state thermal analysis using "ansys"", International Journal of Mechanical and Production Engineering Research and Development, vol. 9, no. 3, pp. 197-204.

22. Ravi, D. 2019, "CFD simulation of solar loading in car", International Journal of Mechanical and Production Engineering Research and Development, vol. 9, no. 3, pp. 231-236

\section{AUTHORS PROFILE}

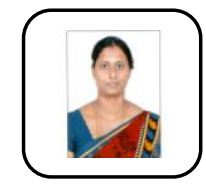

C.M. Meenakshi Assistant Professor, Department of Mechanical Engineering, Bharath Institute of Higher Education and Research, Chennai, India.

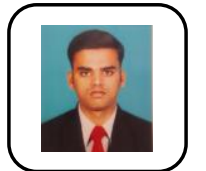

Jeeva Bharathi Assistant Professor, Department of Mechanical Engineering, Bharath Institute of Higher Education and Research, Chennai, India.

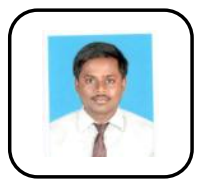

S Karthikeyan Assistant Professor, Department of Mechanical Engineering, Bharath Institute of Higher Education and Research, Chennai, India. 